\title{
Pengaruh Perubahan Fisik Lingkungan Terhadap Perubahan Kesejahteraan Masyarakat Pada Program Relokasi Permukiman BaNTARAN SUngai BENGaWAN SOLO Kota SURAKarTa
}

\author{
Priscilia Nurvita Bella, Winny Astuti, Galing Yudana \\ Program Studi Perencanaan Wilayah dan Kota, \\ Jurusan Arsitektur, Fakultas Teknik \\ Universitas Sebelas Maret, Surakarta \\ email : priscilia.bella24@gmail.com
}

\begin{abstract}
Resettlement in Surakarta City caused by floods in 2007, but rises some problems after resettlement among other high price of housing land, the community economic which is low causes the low of house affordability too, and the government regulation which is less emphatic in limiting settlements growth in inappropriate land. It makes a problem how the implications of the physical environment to the changes of community welfare in resettlement programme of Bengawan Solo river bank in Surakarta City. The analytic-method of this research are paired samples t-test to know the changes of physical environment and community welfare, then regression linear to know the implications of the physical environment to the changes of community welfare. The result from this research is there is strong implication of improvement of physical environment to the changes of community welfare. The implication of two variabel is linear, it means that every improvement of physical environment have an impact to improvement of community welfare and otherwise.
\end{abstract}

Keywords : squatter settlement, resettlement, physical environment, community welfare, paired samples $t$-test, regression linear

\section{PENDAHUluAN}

Kota Surakarta memiliki masalah vital terkait perumahan dan permukiman yaitu tumbuhnya permukiman di lahanlahan yang tidak sesuai dengan peruntukannya. Hal tersebut disebabkan oleh kurangnya akses akan rumah yang layak huni karena tingginya harga lahan karena perekonomian masyarakat yang rendah menyebabkan daya beli terhadap rumah juga rendah, serta kebijakan pemerintah yang kurang tegas dalam membatasi pertumbuhan permukiman di lahan yang bukan peruntukannya. Selain itu dilatarbelakangi oleh bencana banjir yang melanda pada tahun 2007, yang berdampak pada 1.571 rumah di bantaran Sungai Bengawan Solo (Bapermas, 2014).

Mengingat setiap keluarga Indonesia layak menempati rumah yang layak huni, kemudian dikeluarkan kebijakan terkait permasalahan tersebut yaitu relokasi (resettlement) dimana program yang dimulai pada tahun 2008 ini bertujuan untuk merelokasi rumah yang berada di lahan ilegal (bantaran), menata kembali lahanlahan bantaran Sungai Bengawan Solo, serta meningkatkan kesejahteraan masyarakat di lokasi yang baru. Program relokasi dinyatakan cukup berhasil namun seiring terlaksananya program relokasi, muncul isu permasalahan antara lain pendapatan yang tidak sebanding dengan biaya pengeluaran karena lokasi rumah yang cukup jauh dari fasilitas kota seperti sekolah, rumah sakit, dll. Selain itu muncul isu kurangnya keswadayaan masyarakat, dimana masyarakat kurang mampu menggali dan mengembangkan potensi yang ada dalam meningkatkan taraf hidup di lokasi rumah yang baru.

Permasalahan tersebut cukup menjadi perhatian Pemerintah Kota Surakarta khususnya Bapermas yang menangani program relokasi ini secara langsung. Perubahan fisik lingkungan yang terjadi merupakan hasil dari relokasi yang sudah terlaksana. Namun jika dilihat dari sisi lain masih banyak muncul permasalahan terkait aspek ekonomi dan sosial. Brooks, dkk (2005) menjelaskan bahwa relokasi menyebabkan perubahan positif terhadap kondisi lingkungan sosial, ekonomi, perumahan. Hal ini juga yang diharapkan pemerintah Kota Surakarta terjadi perubahan dalamhal kesejahteraan masyarakatnya baik dari segi ekonomi maupun sosialdi lokasi yang baru. Tujuan dari penelitian ini adalah untuk mengetahui pengaruh perubahan fisik lingkungan terhadap perubahan kesejahteraan masyarakat pada program relokasi permukiman bantaran Sungai Bengawan Solo Kota Surakarta. 


\section{METODE}

\subsection{Ruang Lingkup}

Penelitian ini dilakukan di daerah tujuan relokasi yaitu Ngemplak Sutan, Solo Elok, KedungTungkul, Mertoudan, Kaplingan, Mipitan, Sabrang Lor, Jebres Tengah, Tawang Sari, Sangkrah, Laban, Gadingan, Kepuhsari, Meletan, Soroyudan, dan Parangjoro. Dalam penelitian ini variabel fisik lingkungan dibatasi oleh $8 \mathrm{sub}$ variabel yaitu ketersediaan prasarana jalan, ketersediaan prasarana sanitasi, ketersediaan prasarana listrik, ketersediaan prasarana air bersih, ketersediaan prasarana persampahan, lokasi rumah, ketersediaan fasilitas kesehatan, dan ketersediaan fasilitas pendidikan. Sedangkan variabel kesejahteraan masyarakat dibatasi oleh 11 sub variabel yaitu akses terhadap tempat kerja, pendapatan, keswadayaan masyarakat, keamanan, akses transportasi publik, akses sanitasi, akses listrik, akses air bersih, akses persampahan, akses terhadap fasilitas kesehatan, dan akses terhadap fasilitas pendidikan.

\subsection{Metode Analisis}

Analisis dalam penelitian ini terdiri dari tiga tahapan yaitu analisis perubahan fisik lingkungan sebelum dan sesudah relokasi dan analisis perubahan kesejahteraan masyarakat sebelum dan sesudah relokasi dengan metode uji $t$ berpasangan, sedangkan analisis pengaruh perubahan fisik lingkungan terhadap perubahan kesejahteraan masyarakat dengan metode regresi linier.

\section{HASIL DAN PEMBAHASAN}

\subsection{Analisis Perubahan Fisik Lingkungan}

Perubahan fisik lingkungan sebagian besar mengalami peningkatan. Sebesar $62,5 \%$ kondisi fisik lingkungan mengalami peningkatan, sisanya mengalami penurunan. Kondisi fisik lingkungan sebagian besar mengalami peningkatan karena program relokasi yang telah terealisasi. Relokasi yang dilaksanakan memberikan dampak positif terhadap perubahan kondisi fisik lingkungan. Perubahan utama yang terjadi adalah peningkatan legalitas tanah, lokasi rumah terhadap potensi banjir, serta peningkatan ketersediaan prasarana pendukung perumahan.

Peningkatan tertinggi kondisi fisik lingkungan terjadi pada lokasi rumah. Hal ini terjadi karena setelah relokasi masyarakat telah mendapatkan rumah dengan status tanah legal serta lokasi rumah yang aman dari bencana banjir. Sedangkan penurunan terjadi pada ketersediaan prasarana jalan, fasilitas kesehatan, dan fasilitas pendidikan karena di lokasi yang baru jaraknya lebih jauh untuk ditempuh oleh masyarakat dari lokasi rumahnya (tabel perubahan fisik lingkungan dapat dilihat di lampiran).

\subsection{Analisis Perubahan Kesejahteraan} Masyarakat

Perubahan kesejahteraan masyarakat sebagian besar mengalami peningkatan. Sebesar 63,6\% kondisi kesejahteraan masyarakat mengalami peningkatan, sisanya mengalami penurunan. Kondisi kesejahteraan masyarakat sebagian besar mengalami peningkatan karena diintervensi oleh peningkatan fisik lingkungan yang berpengaruh besar. Dari segi ekonomi peningkatan yang paling berpengaruh adalah akses masyarakat terhadap tempat kerja.

Peningkatan tertinggi kondisi fisik lingkungan terjadi pada keamanan masyarakat. Hal ini terjadi karena setelah relokasi masyarakat telah mendapatkan rumah dengan status tanah legal sehingga aman dari penggusuran serta lokasi rumah yang aman dari bencana banjir. Sedangkan penurunan terjadi pada akses masyarakat terhadap transportasi umum, fasilitas kesehatan, dan fasilitas pendidikan karena jaraknya lebih jauh untuk ditempuh masyarakat dengan berjalan kaki sehingga aksesnya lebih sulit. Hal lain yang sangat berpengaruh adalah akses masyarakat terhadap tempat kerja, walaupun peningkatan yang terjadi tidak signifikan namun masyarakat lebih kreatif untuk membuka usaha baru di lokasi rumah yang baru dalam meningkatkan taraf hidup ditandai dengan peningkatan pendapatan (tabel perubahan kesejahteraan masyarakat dapat dilihat di lampiran).

3.3 Analisis Pengaruh Perubahan Fisik Lingkungan terhadap Perubahan Kesejahteraan Masyarakat

Dari hasil analisis regresi pengaruh perubahan fisik lingkungan terhadap perubahan kesejahteraan masyarakat menunjukkan bahwa memang ada pengaruh yang kuat antara perubahan fisik lingkungan terhadap perubahan kesejahteraan masyarakat yang didapat dari uji $\mathrm{t}$ dan korelasi Pearson yang dilakukan. Selain itu dari uji $F$ terlihat bahwa pengaruhnya signifikan antara perubahan fisik lingkungan terhadap perubahan kesejahteraan masyarakat dengan persentase sebesar $57,8 \%$.

Dalam teori Planning and Housing Development (2002) dalam Santosa (2009) dijelaskan bahwa tujuan dari pembangunan 
rumah adalah peningkatan kondisi fisik lingkungan rumah, sosial, dan ekonomi. Kegiatan pembangunan menghasilkan dampak bagi lingkungan yakni meningkatnya daya dukung lingkungan dan meningkatnya kualitas hidup manusia yang dapat diukur dari segi ekonomi maupun sosialnya (Wardhana, 2011). Pembangunan rumah yang berkelanjutan bertujuan untuk meningkatkan kesejahteraan masyarakat (Salim, 1990). Kualitas suatu perumahan yang baik perlu ditunjang oleh kualitas dan kuantitas sarana dan prasarana perumahan sehingga mendukung kehidupan perumahan tersebut (Permana, 2009). Jika dikaitkan dengan hasil dari penelitian ini, pembangunan rumah pada program relokasi memberikan hasil pada peningkatan kondisi fisik lingkungan, sosial, dan juga ekonomi yang dirasakan langsung oleh masyarakat sasaran. Relokasi memberikan dampak nyata pada perubahan fisik lingkungan dan juga berdampak pada aspek kesejahteraan masyarakatnya.

Dalam Astuti (2013) dijelaskan hasil yang didapat dan dirasakan langsung oleh masyarakat sasaran dari program relokasi antara lain kepemilikan lahan legal, peningkatan kualitas hunian, peningkatan jaringan sarana dan prasarana, serta peningkatan manajemen lingkungan dan lingkungan yang lebih terencana. Sedangkan efek ganda yang dihasilkan dari hasil tersebut yaitu kepemilikan aset yang sah mulai mengarah pada perbaikan ekonomi, mulai bermunculan industri kreatif warga, serta mulai adanya perbaikan sikap hidup dan pembiasaan sehari-hari yang lebih baik seiring dengan perbaikan hunian dan lingkungannya. Sedangkan menurut Brooks, dkk (2005) bahwa relokasi menyebabkan perubahan positif terhadap kondisi lingkungan sosial, ekonomi, perumahan. Jika dikaitkan dengan hasil dari penelitian ini, terdapat pengaruh perubahan fisik lingkungan terhadap perubahan kesejahteraan masyarakat. Perubahan fisik lingkungan sebagai hasil dari program relokasi memberikan efek ganda pada kondisi sosial dan ekonomi. Hal tersebut menyebabkan perubahan pula pada kesejahteraan masyarakatnya baik dari segi sosial maupun ekonomi. Perubahan yang terjadi merupakan perubahan yang positif dimana terjadi peningkatan fisik lingkungan yang berpengaruh pula peningkatan kesejahteraan masyarakatnya (tabel dan diagram pengaruh perubahan fisik lingkungan terhadap perubahan kesejahteraan masyarakat dapat dilihat di lampiran).

\section{KESIMPULAN}

Dalam penelitian ini program relokasi merupakan bagian dari program penanganan permukiman kumuh.Dari relokasi yang telah terealisasi terjadi perubahan fisik lingkungan dan didominasi dengan peningkatan pada kondisi fisik lingkungan. Hal tersebut selaras dengan perubahan kesejahteraan masyarakat yang ditandai dengan peningkatan pada kondisi ini. Artinya, perubahan fisik lingkungan yang terjadi pada program relokasi memiliki pengaruh terhadap perubahan kesejahteraan masyarakat. Legalitas rumah dan lokasi yang jauh dari potensi banjir, ketersediaan sarana prasarana penunjang rumah yang terjangkau dan memadai berdampak besar terhadap keamanan masyarakat terhadap banjir dan penggusuran, akses masyarakat akan pelayanan prasarana penunjang rumah, dan akses masyarakat untuk bekerja dalam meningkatkan taraf hidupnya.

Dapat disimpulkan bahwa kondisi fisik lingkungan diikuti oleh kondisi kesejahteraan masyarakat. Perubahan fisik lingkungan yang terjadi pada program relokasi berpengaruh terhadap perubahan kesejahteraan masyarakat. Dalam penelitian ini menunjukkan bahwa terjadinya peningkatan fisik lingkungan berpengaruh pada peningkatan kesejahteraan masyarakat.

\section{REFERENSI}

Astuti, Winny. 2013. Karakteristik "Community-Based Housing Development" dan Kontribusinya terhadap Pengentasan Kemiskinan. Surakarta : Universitas Sebelas Maret

Badan Pemberdayaan Masyarakat, PP, KB dan PA Kota Surakarta. 2014. "Daftar Warga Penerima Hibah (WPH) Korban Banjir Tahun 2007 di Bantaran Sungai (Tanah Negara) Kota Surakarta"

Brooks, F, dkk (2005). Resident perception of housing, neighborhood, and economic conditions after relocation from public housing undergoing HOPE VI redevelopment. Research on Social Work Practice, 15, 481-490

Permana, A. 2009. Studi Ketersediaan Sarana Prasarana berdasarkan Standar dan Penilaian Penghuni Perumnas Bukit Beringin Lestari Kota Semarang. Universitas Diponegoro

Salim, E. 1990. Konsep Pembangunan Berkelanjutan. Jakarta

Santosa, Happy. dkk. 2009. "Sustainable Slum Upgrading in Urban Area”. Surakarta : Unit Research and Empowerment of Housing and Human Settlements Resources PIPW LPPM UNS

Wardhana, A. 2001. Dampak Pencemaran Lingkungan Yogyakarta. Andi 


\section{LAMPIRAN}

Lampiran 1.Perubahan Fisik Lingkungan

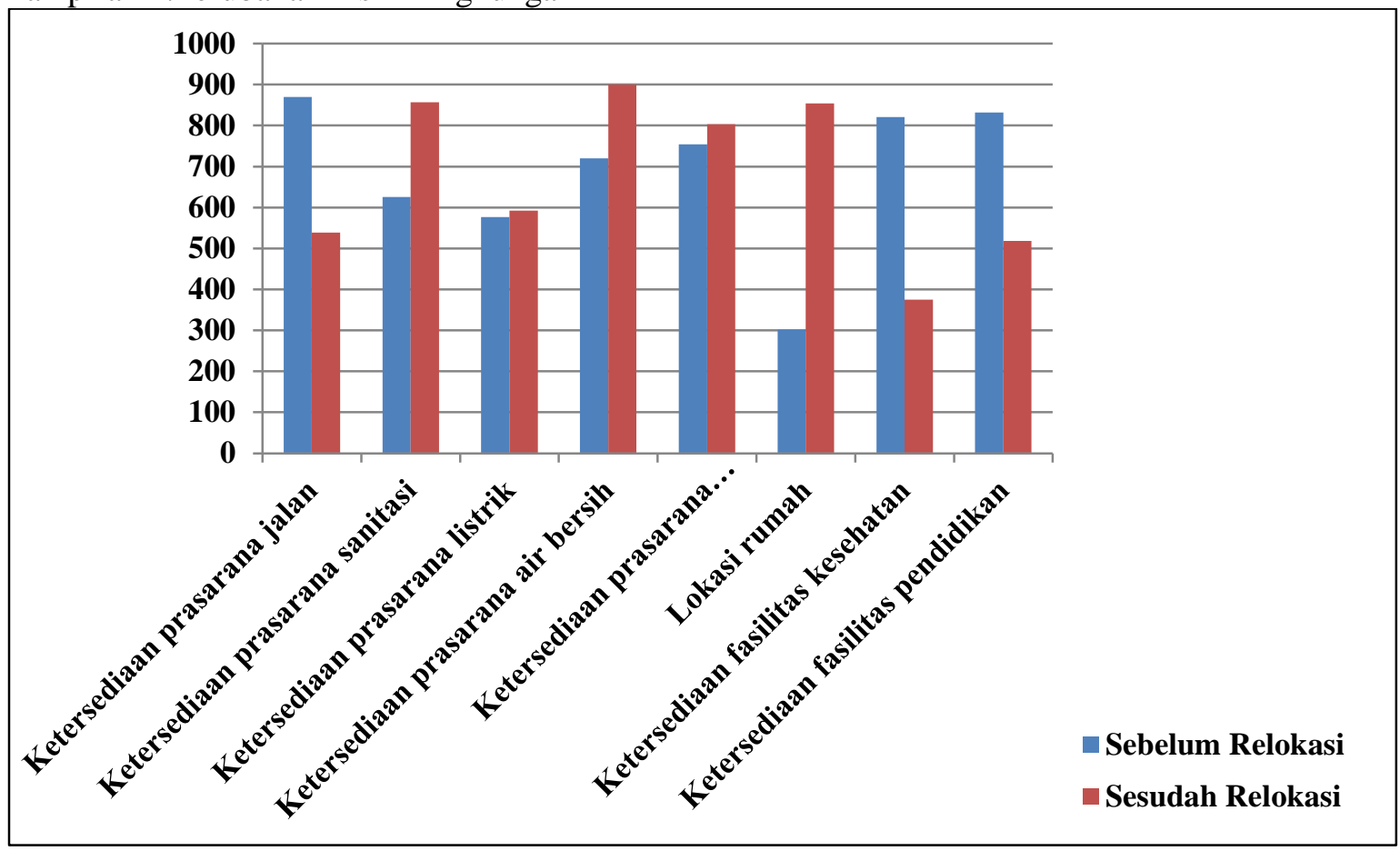

Sumber : Hasil Analisis Penulis, 2015

Lampiran 2.Perubahan Kesejahteraan Masyarakat

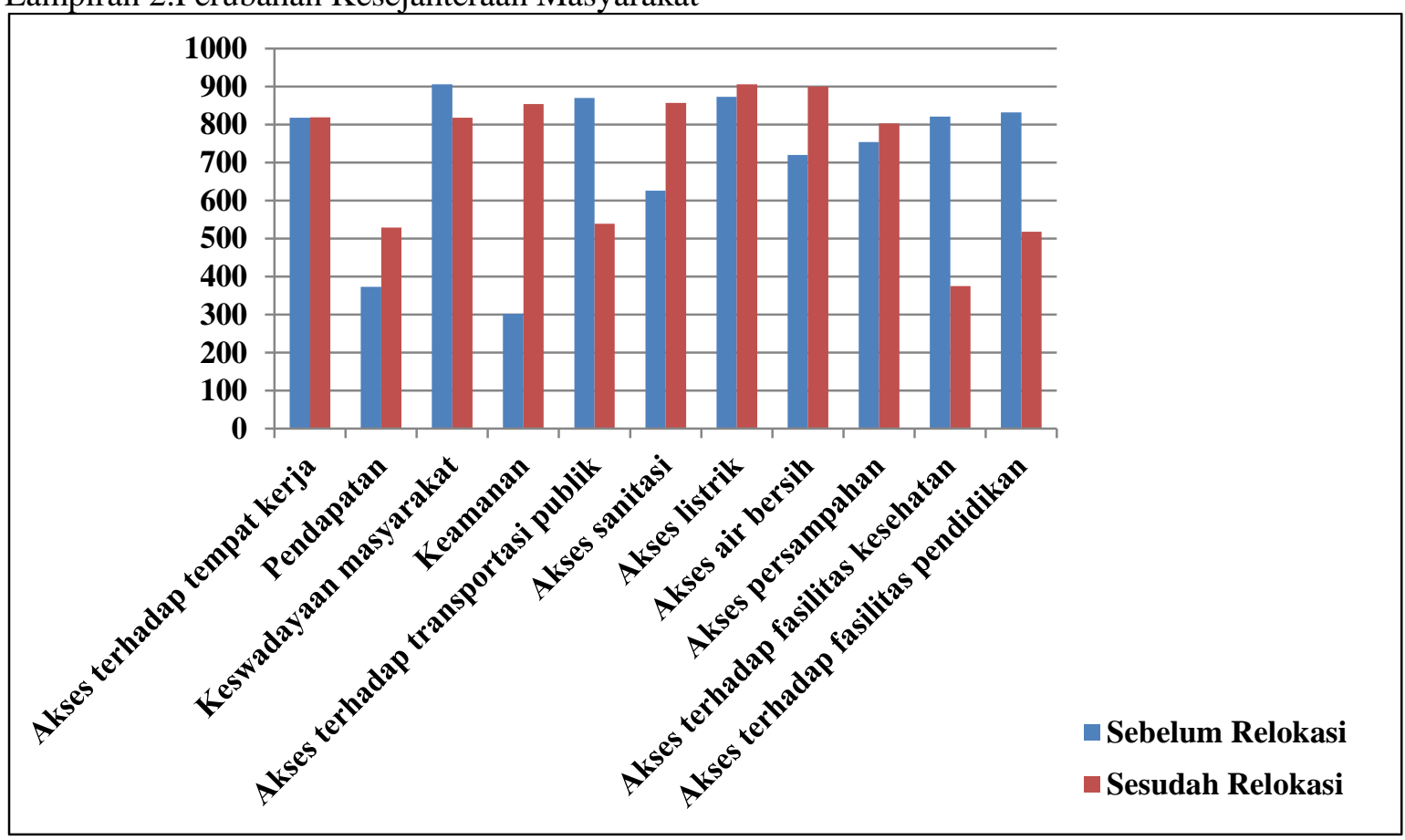

Sumber : Hasil Analisis Penulis, 2015

Lampiran 3.Hasil Regresi Linier Pengaruh Perubahan Fisik Lingkungan terhadap Perubahan Kesejahteraan Masyarakat

\begin{tabular}{|c|c|c|c|c|c|c|c|c|c|}
\hline \multirow[b]{2}{*}{ Model } & \multirow{2}{*}{$\begin{array}{l}\text { Korelasi } \\
\text { Pearson } \\
(\mathbf{R})\end{array}$} & \multicolumn{2}{|c|}{$\begin{array}{l}\text { Koefisien } \\
\text { Determinasi }\end{array}$} & \multicolumn{3}{|c|}{ Uji Parsial (t-test) } & \multicolumn{3}{|c|}{ Uji Simultan $(F$ test $)$} \\
\hline & & $\begin{array}{l}\mathbf{R} \\
\text { Square } \\
\left(\mathbf{R}^{2}\right)\end{array}$ & $\begin{array}{l}\text { Persentase } \\
(\%)\end{array}$ & ttabel & thitung & Sig. & $\mathbf{F}_{\text {tabel }}$ & F hitung & Sig. \\
\hline $\begin{array}{l}\text { Regresi } \\
\text { Linier }\end{array}$ & .761 & .578 & 57.8 & 2.253 & 20.290 & .000 & 2.041 & 411.699 & .000 \\
\hline
\end{tabular}

Sumber : Analisis SPSS, 2015 